\title{
Comparison of Some Biomechanical Properties of Tibiotarsus in Four Different Feather Color Lines of 60-Day Old Female Quails
}

\section{-Author(s)}

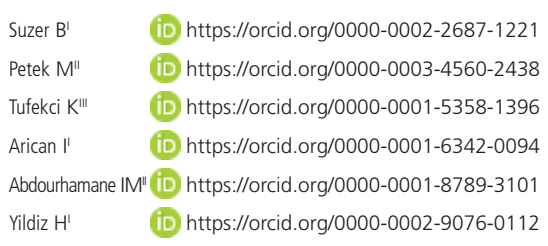

Department of Anatomy, Faculty of Veterinary Medicine, Bursa Uludag University, Bursa, Turkey.

Department of Zootechnics, Faculty of Veterinary Medicine, Bursa Uludag University, Bursa, Turkey.

Department of Mechanics, Faculty of Engineering, Bursa Uludag University, Bursa, Turkey.

\section{Mail Address}

Corresponding author e-mail address Bayram Suzer

Bursa Uludag Univeristesi Veteriner Fakultesi Anatomi AD 16059 Nilufer, Bursa, Turkey.

Phone: +905534451638

Email: suzer@uludag.edu.tr

\section{- Keywords}

Bone strength, feather mutation, quail tibiotarsus.

\section{ABSTRACT}

This study aimed to compare some morphological and mechanical measurements of four different color female quails to contribute to the formation of the morphological database.

Quails are the smallest farmed avian species which are becoming more important for the poultry industry. They are also used as experimental animals and are valuable birds for researches. Genetic factors are important determinants of bone strength. Thus, skeletal disorders may be reduced by breeding selection in quails. Forty female quails with four different feather colors, including wild, white, yellow, and black, were compared at 60 days of age. Each quail group contained ten individuals. A three-point bending test was performed with a custom-made testing machine designed for low strength materials. No significant difference was found between the groups in terms of body weight. The tibiotarsus weight in wild and black $(0,665 \pm 0,055 \mathrm{~g}$ and $0,687 \pm 0,025 \mathrm{~g}$, respectively) was significantly lower than in the others but, the significant highest value was in white quails $(0,758 \pm 0,063 g)(p=0.001)$. Significantly shorter tibiotarsus was observed in the black quails $(51,286 \pm 1,374 \mathrm{~mm})$, while the tibiotarsi of the white and yellow quails were the tallest $(53,216 \pm 1,796 \mathrm{~mm}$ and $53,083 \pm 1,092 \mathrm{~mm}$, respectively) $(p=0.005)$. There were no significant differences among the groups in the biomechanical properties of tibiotarsus, except stiffness. Stiffness was the highest in the white quails $(109,500 \pm 3,807 \mathrm{~N} / \mathrm{mm})$ and the lowest in the black quails $(99,000 \pm 9,498 \mathrm{~N} / \mathrm{mm})(p=0.042)$. In conclusion, white quails have been observed to have relatively better bone biomechanical properties compared to the other color groups at 60 days of age.

\section{INTRODUCTION}

Different poultry species are being used for food production and protecting genetic resources, although egg and meat production in the world is based mainly on chicken production (Hassan, 2013). One of those species, quail, is the smallest farmed avian species which is becoming more significant for egg and meat production industries (Minvielle, 2004).

Besides breeding for egg or meat production, quails are also used as an experimental animal and is a valuable bird for researches. The use of Japanese quails in biomedical research is becoming widespread (Minvielle, 2004) and has been widely used for biological and genetic studies. Quails are useful sources for researchers because of their high egg production rates, intensive growth rate, early sexual maturity, short generation interval, low maintenance costs as well as their small body size and resistance to diseases (Yildiz \& Kesici, 1999; Minvielle et al., 2007; Tarhyel et al., 2012; Hassan, 2013).

Genetic factors are important determinants of bone strength (Rath et al., 2000). The effects of genetic factors on bone strength have been 
tested by several studies on rats, mice and laying hens (Bishop et al., 2000; Szumska et al., 2007; Alam et al., 2011). Since $30 \%$ to $80 \%$ of the variance in tibia breaking strength is genetically determined for broiler chickens (Mandour et al., 1989; de Verdal et al., 2013) and White Leghorn hens (Bishop et al., 2000), skeletal system disorders may be reduced by genetic selection (Bishop et al., 2000) that seems to be effective behind nutrition to improve bone strength (Fleming, 2008). There are some studies on skeletal formation, including effects of age and sex on bone development, and effects of feed additives on performance traits and bone tissue properties of pelvic limb bones (Kara et al., 2012; Kolas \& Kara, 2013; Tufan et al., 2014). Further, quails with different colors attracted the attention of the researchers. Several researchers have studied several feather color mutations such as rusty (Minvielle et al., 2005), white (Petek et al., 2004; Inci et al., 2015, Taha et al., 2019), dark brown, golden (Inci et al., 2015, Taha et al., 2019), roux (Minvielle et al., 1999), lavender (Bed'hom et al., 2012) and wild-type (Petek et al., 2004; Minvielle et al., 2005; Bed'hom et al., 2012; Inci et al., 2015) and their effects on some growth performance parameters. However, there is no study comparing bone biomechanical studies of quail with different feather colors.

In the present study, wild, white, yellow, and black color quails were compared in some basic morphological and mechanical traits. To date, morphological and biomechanical properties of tibiotarsus of selected quails have not been compared. Therefore, this study aimed to compare some morphological and mechanical measurements of four different colored female quails to contribute to the formation of the morphological database.

\section{MATERIALS AND METHODS}

\section{Animals and collection of bones}

The study was performed on the tibiotarsi of four different breeds of quails. The tibiotarsi bones were obtained from quail raised for production at Bursa
Uludag University Animal Production Research and Application Center Quail Production Unit including one pure line stocks as 'wild' and their recessive white variety 'white' quail of the Pharaoh strain (Coturnix coturnix pharaoh) and two cross-line stocks of yellow and black color quail. The white line was set up from mutant birds, which appeared spontaneously in a wildtype quail colony, and after initial crossing, they were fixed. The crosslines ('yellow' and 'black' colored) were obtained from pure line stocks of Coturnix coturnix japonica and pure line stocks of Bob White. The visual properties of each line were presented in Figure 1. Each quail group contained ten individuals. All birds were kept in the same feeding conditions and living environment and were slaughtered on 60 days of age. Birds in all groups were reared at $31-33{ }^{\circ} \mathrm{C}$ in week $1,27-31{ }^{\circ} \mathrm{C}$ in week $2,23-26{ }^{\circ} \mathrm{C}$ in week $3,20-23$ ${ }^{\circ} \mathrm{C}$ in week 4 and $18-21^{\circ} \mathrm{C}$ in weeks 5 to 6 . Newly hatched chicks in all groups were housed in the same environmental conditions (floor space, bird density, feeder, and drinker space) in a multitier cage during the growing period. Birds on all groups consumed ad libitum a commercial maize-based grower ration from 1 to $45 \mathrm{~d}$ of age $(\mathrm{ME}=12.50 \mathrm{MJ} / \mathrm{kg}, 220 \mathrm{~g} / \mathrm{kg}$ total protein) and a finisher ration from 45 to $60 \mathrm{~d}$ of age (ME $=12.70 \mathrm{MJ} / \mathrm{kg}, 200 \mathrm{~g} / \mathrm{kg}$ total protein). Quails received continuous light, including natural daylight during daytime and artificial light during the night. Chick weight at hatch and final bodyweight of the birds in the groups were measured individually, and weight gain during the growing period was calculated. The right tibiotarsi were collected from each bird, dissected surrounding soft tissues, and then frozen in plastic bags at $-20^{\circ} \mathrm{C}$ until mechanical tests and cortical area analysis were conducted (Swiatkiewicz \& ArczewskaWlosek, 2012).

\section{Biomechanical tests}

Tibiotarsi were thawed in room temperature, and then they were weighed with a Precisa XB4200C digital scale (Precisa Instruments Ltd., Switzerland). Length measurements were applied with Mitutoyo CDN-20C digital caliper (Mitutoyo Corp., Kawasaki, Japan).

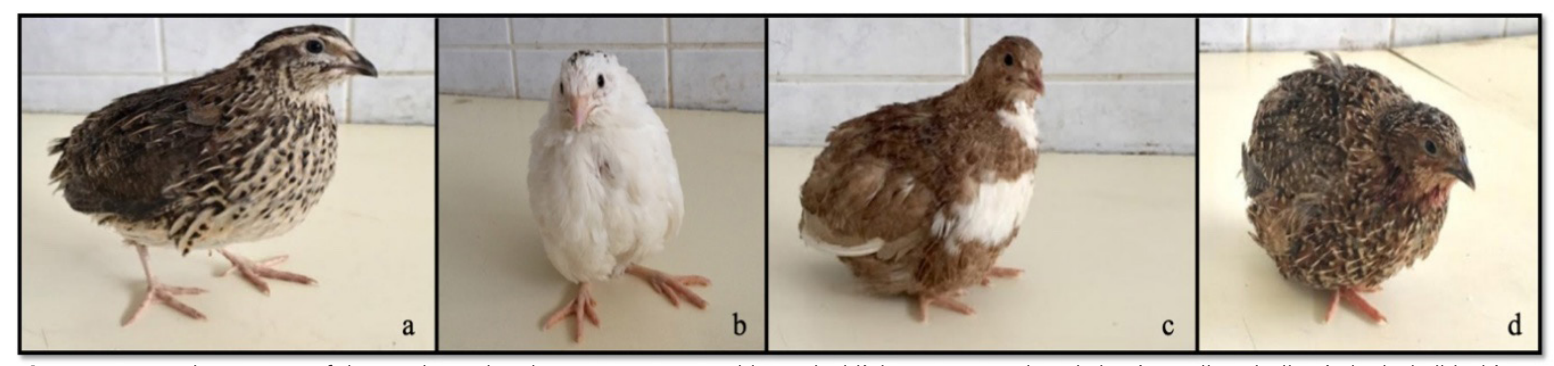

Figure 1 - Visual properties of the quails used in the experiment. a: Wild-type 'wild', b: Recessive white, 'white', c: Yellow, 'yellow', d: Black, 'black' 
Three-point bending tests were performed with a custom-made testing machine, which was designed for low strength materials at the Mechanical Engineering Department of Suleyman Demirel University in Isparta, Turkey (Tufekci et al., 2014). A load-cell $(50$ kg, Tedea Huntleigh Malvern, USA) and a Linear Variable Differential Transformer (LVDT) (10-mm stroke, Novotechnik Tr10, Germany) were used to measure force and corresponding displacement during tests, respectively. A four-channel oscilloscope (100 data/ sec, Nicholet-Oddysey XE, USA) was used to record the measured data from both transducers. The oscilloscope has its own software and gives the load-cell and LVDT data in the dimension of voltages. These data were converted to Newton and mm using the formulations presented by the manufacturer in Microsoft Excel. The experimental results could be affected by loading head speed rate. Therefore, all tests were performed at a constant loading head speed of $10 \mathrm{~mm} / \mathrm{min}$, as suggested by a previous study (Lopez \& Markel, 2000). The average length of the whole bone tested was $50 \mathrm{~mm}$, so the span between support was set to 20 $\mathrm{mm}$, which is $40 \%$ of the total bone length, and the force was applied at the middle of the span (Figure 2). Three-point bending test provided ultimate strength, stiffness, displacement, and work-to-fracture.

\section{Statistical analysis}

Data for the measured parameters were normally distributed and met the assumptions for homogeneity of variance. For each measured parameter, the mean for each experimental group and the standard errors were calculated in SPSS (SPSS, Version 23.0, Chicago, IL). Data were presented as mean \pm standard error of the mean. For statistical evaluation, one-way ANOVA test was used. Differences were accepted as $p \leq 0.05$ significant. When the differences between the groups were significant $(p \leq 0.05)$, data were assessed by Tukey HSD to determine groups that the difference originated from (Snedecor \& Cochran, 1989).

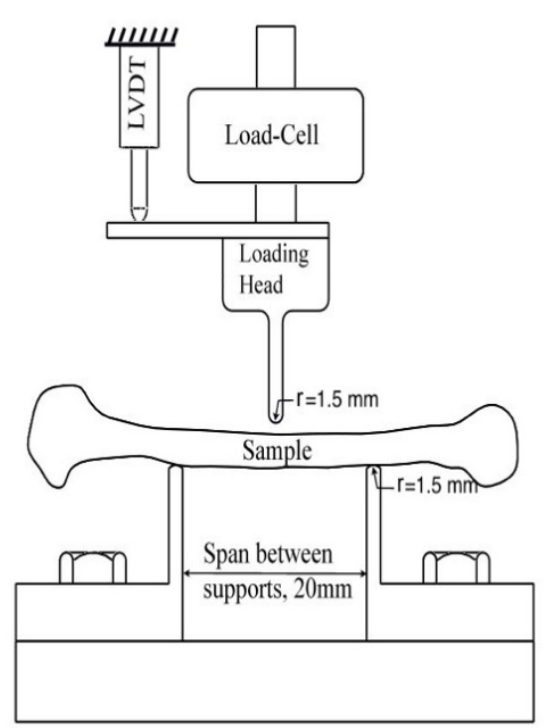

Figure 2 - Schematic drawing of the three-point bend fixture.

*LVDT: Linear Variable Differential Transformer, r: Radius of crosshead and supports.

\section{RESULTS}

Chick weight, final body weight, and morphological and mechanical measurements of quails tibiotarsus were presented in Table 1. There were no significant differences between the groups in terms of chick weight at the beginning of the study $(p=0.883)$. At the end of 60 days period, no significant difference was found between the groups in terms of body weight $(p=0.160)$. White quails had the heaviest tibiotarsus $(0.758 \pm 0.063 \mathrm{~g})$ significantly compared to other groups. But, the weight of tibiotarsus in wild and black quails was remarkably lower than the others $(p=0.001)$, and the tibiotarsus weight for wild and black quails was $0.665 \pm 0.055 \mathrm{~g}$ and $0.687 \pm 0.025 \mathrm{~g}$, respectively. There was no difference in tibiotarsus weight between yellow quails $(0.719 \pm 0.038 \mathrm{~g})$ and the other quails. With the $51.286 \pm 1.374 \mathrm{~mm}$ tibiotarsus length, black quails had significantly shorter tibiotarsus length than other quails, whereas white, and yellow quails had the tallest tibiotarsus ( $p=0.005$ ) with the length of $53.216 \pm 1.796$

Table 1 - Chick weight, final body weight, and morphological and biomechanical measurements of tibiotarsus of quails.

\begin{tabular}{lcccccccc}
\hline & Chick weight $(\mathrm{g})$ & $\begin{array}{c}\text { Final Body } \\
\text { weight }(\mathrm{g})\end{array}$ & Bone weight $(\mathrm{g})$ & $\begin{array}{c}\text { Bone length } \\
(\mathrm{mm})\end{array}$ & $\begin{array}{c}\text { Ultimate } \\
\text { strength }(\mathrm{N})\end{array}$ & $\begin{array}{c}\text { Stiffness } \\
(\mathrm{N} / \mathrm{mm})\end{array}$ & $\begin{array}{c}\text { Displacement } \\
(\mathrm{mm})\end{array}$ & $\begin{array}{c}\text { Work-to-fracture } \\
(\mathrm{Nmm})\end{array}$ \\
\hline Wild $(\mathrm{n}=10)$ & $7.77 \pm 0.14$ & $181.20 \pm 22.82$ & $0.687 \pm 0.008^{\mathrm{a}}$ & $51.76 \pm 0.29^{\mathrm{ab}}$ & $43.01 \pm 2.45$ & $99.000 \pm 3.00^{\mathrm{a}}$ & $0,513 \pm 0.02$ & $12,948 \pm 0.76$ \\
\hline $\begin{array}{l}\text { Recessive } \\
\text { white }(\mathrm{n}=10)\end{array}$ & $7.91 \pm 0.24$ & $180.92 \pm 22.90$ & $0.758 \pm 0.020^{\mathrm{b}}$ & $53.21 \pm 0.56^{\mathrm{b}}$ & $41.59 \pm 0.94$ & $109.500 \pm 1.20^{\mathrm{b}}$ & $0,463 \pm 0.02$ & $11,164 \pm 0.92$ \\
Yellow $(\mathrm{n}=10)$ & $8.02 \pm 0.22$ & $169.98 \pm 21.63$ & $0.719 \pm 0.012^{\mathrm{ab}}$ & $53.08 \pm 0.34^{\mathrm{b}}$ & $43.14 \pm 1.41$ & $103.500 \pm 3.62^{\mathrm{ab}}$ & $0,524 \pm 0.02$ & $13,364 \pm 0.70$ \\
\hline Black $(\mathrm{n}=10)$ & $7.91 \pm 0.23$ & $165.81 \pm 23.95$ & $0.665 \pm 0.017^{\mathrm{a}}$ & $51.28 \pm 0.43^{\mathrm{a}}$ & $44.72 \pm 1.38$ & $103.600 \pm 2.29^{\mathrm{a}}$ & $0,525 \pm 0.01$ & $12,818 \pm 0.53$ \\
p-value & 0.883 & 0.160 & 0.001 & 0.005 & 0.615 & 0.042 & 0.293 & 0.407 \\
\hline
\end{tabular}

*Data were presented as mean \pm standard error of the mean. Differences were accepted as $p \leq 0.05$ significant. 
$\mathrm{mm}$ and $53.083 \pm 1.092 \mathrm{~mm}$, respectively. Wild quails had $51.762 \pm 0.924 \mathrm{~mm}$ tibiotarsal length but showed no difference with other quails.

No statistically significant differences were observed among the groups in ultimate strength, displacement, and work-to-fracture $(p=0.615, p=0.293, p=0.407$, respectively). In the biomechanical properties, only stiffness showed a statistical difference $(p=0.042)$, and this value was the highest in the white quails $(109.500 \pm 3.807 \mathrm{~N} / \mathrm{mm})$ and the lowest in the black quails $(99.000 \pm 9.498 \mathrm{~N} / \mathrm{mm})$.

\section{DISCUSSION}

In the presentstudy, we comparesome morphological and mechanical characteristics of female quails with different colors, including wild, white and yellow.

Several researchers documented many quails with different feather colors in the world. Some of them were white, brown, roux, yellow, rusty, and wild type (Minvielle et al., 2005). In general, researchers have focused on and compared the effects of different feather color and type on growth performance (Minvielle et al., 1999; Petek et al., 2004; Minvielle et al., 2005; Bed'hom et al., 2012; Inci et al., 2015). However, there is a lack of information on the biomechanical comparisons of these quails.

In our study, live weight for wild, white, yellow, and black quails were 181.20 $222.82,180.92 \pm 22.90$, $169.98 \pm 21.63$ and $165.81 \pm 23.95$, respectively. Although black and white quails were observed numerically to be heavier than others, the difference was not statistically significant. In contrast to our study, Minvielle et al. (1999) and Inci et al. (2015) stated that feather color had a significant effect on live bodyweight and that the wild-type quails had a higher body weight. Some studies have also observed that white quails had less body weight than wild-type quails (Petek et al., 2004; Minvielle et al., 2005; Yilmaz \& Caglayan, 2008). Petek et al. (2004) and Minvielle et al. (2007) have reported that recessive white color has a depressive effect on quail body weight. But we did not observe this depressive effect on the body weight of white quails. Because no difference was found between wild and white quails, the scarcity of previous morphological and mechanical comparison studies in the quails was a handicap to make the biomechanical comparisons. Several studies suggested that tibiotarsus may serve as model bones in studies on the quality of the skeleton of poultry (Church \& Johnson 1964; Tatara et al., 2005; Charuta et al., 2013). Also, tibial length has been used as an indicator of linear growth (Masoud et al., 1986; Fritton et al., 2005). In the present study, the significantly higher values in tibiotarsal length and weight of white quails compared to other color quails showed that the growth rate of white quails was better than others. Tibiotarsi of white quails were also stiffer than others. With higher stiffness value in white quails, greater ultimate strength and lower displacement values are expected because stiffer structures deform less for a certain load than more compliant structures (Jepsen et al., 2015). But the ultimate strength and displacement values were not statistically significant among the groups. Stiffness depends on bone geometry and bone material properties (Jepsen et al., 2015). Therefore, the increase of the stiffness in white quails may be a result of better morphology of the tibiotarsus due to higher weight and length of white quails. Also, in poultry, medullary bone formation increases with the onset of the laying period (Whitehead \& Wilson 1992). It is stated that the bone strength increases with the increase of the medullary bone formation (Fleming et al., 1998). Kaczanowska-Taraszkiewicz (2001) also reported that Pharaoh quails have started to lay at the age of 8 weeks, and due to the presence of medullary bone, the mechanical properties of the bones were higher in females than males. According to Kaczanowska-Taraszkiewicz (2001), the quails in our study were also 60 days old, and they were around the starting of laying period. We did not collect data about egg production in our experiment. But quails with different colors might start to lay at different periods. This situation may also affect the amount of medullary bone on the day of the experiment. Various amounts of medullary bone formation may cause differences in biomechanical values. Therefore, further studies are required to evaluate the laying age, feather color and their effects on bone properties in quails.

\section{CONCLUSION}

In conclusion, none of the color groups seem superior to the others when all biomechanical properties were considered. There was no difference in biomechanical characteristics of tibiotarsus except stiffness in female quails with different feather colors including wild, white, yellow and black at 60 days of age. According to these results, white quail has been observed to have relatively better bone biomechanical properties. Furthermore, we concluded that more comprehensive studies are required to determine the relationship between feather color and some morphometric and mechanical measurements in quails. 


\section{Comparison of Some Biomechanical Properties of Tibiotarsus in Four Different Feather Color Lines of 60-Day Old Female Quails}

\section{CONFLICTS OF INTEREST}

The authors hereby declare that we do not have any conflict of interest in regard to the information provided in this study.

\section{REFERENCES}

Alam I, Koller DL, Sun Q, Roeder RK, Cañete T, Blázquez G, et al. Heterogeneous stock rat:a unique animal model for mapping genes influencing bone fragility. Bone 2011;48:1169-1177.

Bed'hom B, Vaez M, Coville JL, Gourichon D, Chastel O, Follett S, et al. The lavender plumage colour in Japanese quail is associated with a complex mutation in the region of MLPH that is related to differences in growth, feed consumption and body temperature. BMC Genomics $2012 ; 13: 442$

Bishop SC, Fleming $\mathrm{RH}$, Mccormagk HA, Flock DK, Whitehead CC. Inheritance of bone characteristics affecting osteoporosis in laying hens. British Poultry Science 2000;41:33-40

Charuta A, Dzierzęcka M, Komosa M, Biesiada-Drzazga B, DziałaSzczepańczyk E, Cooper GR. Age- and sex-related changes in mineral density and mineral content of the tibiotarsal bone in quails during post-hatching development. Kafkas Universitesi Veteriner Fakultesi Dergisi 2013;19:31-36

Church LE, Johnson LC. Growth of long bones in the chicken. rates of growth in length and diameter of the humerus, tibia, and metatarsus. Developmental Dynamics 1964;114:521-538.

De Verdal H, Narcy A, Bastianelli D, Meme N, Urvoix S, Collin A, et al. Genetic variability of metabolic characteristics in chickens selected for their ability to digest wheat. Journal of Animal Science 2013;91:26052615.

Fleming $\mathrm{RH}$. Nutritional factors affecting poultry bone health. Proceedings of the Nutrition Society 2008;67(2):177-183.

Fleming RH, Mccormack HA, Mcteir L, Whitehead CC. Medullary bone and humeral breaking strength in laying hens. Research in Veterinary Science 1998;64:63-67.

Fritton JC, Myers ER, Wright TM, van der Meulen MCH. Loading induces site-specific increases in mineral content assessed by microcomputed tomography of the mouse tibia. Bone 2005;36:1030-1038.

Hassan K. Evaluation of productive performance of japanese quail in summer of Iraq. Diyala Agricultural Sciences Journal 2013;5:69-80.

Inci $H$, Sogut $B$, Sengul T, Sengul AY, Taysi MR. Comparison of fattening performance, carcass characteristics, and egg quality characteristics of Japanese quails with different feather colors. Revista Brasileira de Zootecnia 2015;44:390-396.

Jepsen KJ, Silva MJ, Vashishth D, Guo XE, van der Meulen MCH. Establishing biomechanical mechanisms in mouse models:practical guidelines for systematically evaluating phenotypic changes in the diaphyses of long bones. Journal of Bone and Mineral Research 2015;30:951-966.

Kaczanowska-Taraszkiewicz E. The effect of age and sex on some developmental parameters of quail (Coturnix coturnix Pharaoh) skeletal system. Medycyna Weterynaryjna 2001;57:510-514

Kara K, Sariozkan S, Konca Y, Kocaoglu Guclu B. The effect of supplementation of humate in quail (Coturnix coturnix japonica) diet on fattening performance and revenue. Veteriner Hekimler Dernegi Dergisi 2012;83:17-24

Kolas A, Kara MA. Effect of Organic zinc sources on the performance and bone mineralization in young japanese quails. Tarim Bilimleri Arastirma Dergisi 2013;6:178-182.
Lopez MJ, Markel MD. Bending tests of bone. In: An YH, Draughn RA editors. Mechanical testing of bone and the bone-implant interface. Boca Raton:CRC press;2000 p. 209-210.

Mandour MA, Nestor KE, Sacco RE, Polley CR, Havenstein GB. Genetic parameter estimates for wing bone strength measurements of cagereared broilers. Poultry Science 1989;68:1174-1178.

Masoud I, Shapiro F, Kent R, Moses A. A longitudinal study of the growth of the New Zealand white rabbit:Cumulative and biweekly incremental growth rates for body length, body weight, femoral length, and tibial length. Journal of Orthopaedic Research 1986;4:221-231.

Minvielle $F$. The future of Japanese quail for research and production. World's Poultry Science Journal 2004;60:500-507.

Minvielle F, Gourichon D, Moussu C. Two new plumage mutations in the Japanese quail:"curly" feather and "rusty" plumage. BMC Genetics 2005;6:14.

Minvielle F, Gourichon D, Ito S, Inoue-Murayama M, Rivie S. Effects of the dominant lethal yellow mutation on reproduction, growth, feed consumption, body temperature, and body composition of the Japanese quail. Poultry Science 2007;86:1646-1650.

Minvielle F, Hirigoyen E, Boulay M. Associated effects of the roux feather colour mutation on growth carcass traits, egg production and reproduction of Japanese quail. Poultry Science 1999;78:1479-1484

Petek M, Ozen Y, Karakas E. Effects of recessive white plumage colour mutation on hatchability and growth of quail hatched from breeders of different ages. British Poultry Science 2004;45:769-774.

Rath NC, Huff GR, Huff WE, Balog JM. Factors regulating bone maturity and strength in poultry. Poultry Science 2000;79:1024-1032.

Snedecor G, Cochran W. Statistical methods. $3^{\text {rd }}$ ed. lowa: lowa State University Press; 1989.

Swiatkiewicz S, Arczewska-Wlosek A. Bone quality characteristics and performance in broiler chickens fed diets supplemented with organic acids. Czech Journal of Animal Science 2012·57:193-205.

Szumska D, Beneš H, Kang P, Weinstein RS, Jilka RL, Manolagas SC, et al. A novel locus on the $x$ chromosome regulates post-maturity bone density changes in mice. Bone 2007;40:758-766

Taha AE, El-Tahawy AS, Abd El-Hack ME, Swelum AA, Saadeldin IM Impacts of various storage periods on egg quality, hatchability, posthatching performance, and economic benefit analysis of two breeds of quail. Poultry Science 2019;98:777-784.

Tarhyel R, Tanimomo BK, Hena SA. Organ weight:As influenced by color, sex and weight group in Japanese quail. Scientific Journal of Anima Science 2012:1:46-49.

Tatara MR, Sierant-Rożmiej N, Krupski W, Majcher P, Śliwa E, Kowalik $S$, et al. Quantitative computed tomography for the assessment of mineralization of the femur and tibia in turkeys. Medycyna Weterynaryjna 2005;61:225-228.

Tufan T, Arslan C, Sari M. Effects of clinoptilolite supplementation to Japanese quail diet on growth performance, carcass traits and some blood parameters. Lalahan Hayvancilik Arastirma Enstitusu Dergis 2014:54:21-27.

Tufekci K, Kayacan R, Kurbanoglu C. Effects of gamma radiation sterilization and strain rate on compressive behavior of equine cortical bone. Journal of the Mechanical Behavior of Biomedical Materials 2014;34:231-242.

Whitehead CC, Wilson S. Characteristics of osteopenia in hens In:Whitehead CC, editor. Bone biology and skeletal disorders in poultry. Oxfordshire: Carfax Publishing; 1992. p.265-280

Yildiz MA, Kesici T. Genetic analysis of brown feather colour in quail. Lalahan Hayvancılık Arastirma Enstitusu Dergisi 1999;39:43-46.

Yilmaz A, Caglayan T. Egg weight, shape index and hatch weight in Japanese quails (Coturnix coturnix japonica) with different feather colors. Firat Universitesi Saglik Bilimleri Veteriner Dergisi 2008;22:5-8. 
